"Children of Quality Do Not Linger Long in Woolworths": Concealment, Containment, and Mortification in Clare Boylan's Holy Pictures and Miriam Dunne's Blessed Art Thou A Monk Swimming

\title{
Kelli Maloy
}

\section{(2) OpenEdition}

\section{Electronic version}

URL: http://journals.openedition.org/etudesirlandaises/1790

DOI: 10.4000/etudesirlandaises. 1790

ISSN: 2259-8863

\section{Publisher}

Presses universitaires de Rennes

\section{Printed version}

Date of publication: 30 June 2010

Number of pages: 89-102

ISSN: 0183-973X

\section{Electronic reference}

Kelli Maloy, «"Children of Quality Do Not Linger Long in Woolworths": Concealment, Containment, and Mortification in Clare Boylan's Holy Pictures and Miriam Dunne's Blessed Art Thou A Monk

Swimming », Études irlandaises [Online], 35-1 | 2010, Online since 30 September 2012, connection on 30 April 2019. URL : http://journals.openedition.org/etudesirlandaises/1790 ; DOI : 10.4000/ etudesirlandaises. 1790

\section{This text was automatically generated on 30 April 2019.}

(c) Presses universitaires de Rennes 


\title{
"Children of Quality Do Not Linger Long in Woolworths": Concealment, Containment, and Mortification in Clare Boylan's Holy Pictures and Miriam Dunne's Blessed Art Thou A Monk Swimming
}

\author{
Kelli Maloy
}

Several recent notable studies of Irish literature and culture have focused on the tropes of containment and confinement. Specifically, Kathryn Conrad's Locked in the Family Cell (2004), which uses Foucault's notion of the "family cell", posits that the insistence on the family model silences and excludes even those who are able to access it and that the dichotomy of the public and private, as defined by the cell model, enforces hierarchy, containment, and conflict. Her study examines various aspects of Irish literature and culture, including homosexuality's threat to the family cell and the roles of information and "informer" in the cell model, and identifies the female body as occupied territory in search of subjectivity independent of the national landscape ${ }^{1}$. Using a similar central trope, James M. Smith's Ireland's Magdalen Laundries and the Nation's Architecture of Containment (2007) argues that the Magdalen enterprise, an extension of the church's complicit role in the state-sanctioned culture of sexual containment, concealed and controlled those elements of the population that threatened to disrupt the "fiction of Irish cultural purity". The Magdalen facilities, as a result, became sometimes temporary, often permanent holding cells for unwed pregnant women, victims of rape and incest, and women considered promiscuous or otherwise unmanageable. The result, in theory, was the preservation of the myth of Irish purity and the success of the Catholic Church in maintaining sexual order. 
While the effects of containment persist, the role of modernization is undoubtedly linked to a gradual weakening of many of the channels through which the containment culture and the family cell have operated in Ireland. The closing of the Magdalen Laundries, the legalization of divorce, voter-approved changes to restrictions on abortion, and the ease with which national borders can be crossed have dramatically diminished the ability of the state and the church to maintain the Irish "purity narrative". As a result, literature has begun to reflect a more diverse range of narratives, including those previously contained by apparatuses designed to normatize the national narrative and products of it. Sally Barr Ebest notes in her study of Irish and Irish-American women writers that the "rise of feminism can first be observed in the bildungsromane of the period 1960-1990". Citing among others Clare Boylan and Edna O'Brien, Ebest identifies a new type of female protagonist, one who "is willing to leave her children to gain her freedom" and to abandon the church". Likewise, Tom Inglis argues that "it is not until the 1960s that we begin to see, first in literature and then in film, the emergence of alternative descriptions and images of Irish sexuality. Much of this resistance revolved around women and especially the rejection of the modest, chaste, virginal woman championed by the Catholic church and epitomized by the image of the Virgin Mary".

While these works certainly have predecessors, they are more prevalent now than in previous decades or centuries, and they often respond directly to the modernizing forces that challenge the containment culture and the family cell. Clare Boylan's Holy Pictures (1983) and Miriam Dunne's Blessed Art Thou A Monk Swimming (1997), set in the 1920s and the 1960s, respectively, depict two generations of adolescent female protagonists who both uphold and resist national constructions of female subjecthood. It would seem that the protagonist of the latter, a beneficiary of forty years of modern history, would be more successful in resisting containment, and indeed the options available to her and not to her 1920s counterpart offer her a degree of transnational mobility and economic freedom that allow her to resist the prescribed life common among the women who surround her in 1960s Dublin. At the same time, Boylan, while locating her protagonist in a setting that is still highly effective in containing its citizens, and particularly its female citizens, suggests more subtle ways in which the containment culture and the family cell might be subverted.

4 The protagonist of Holy Pictures, set in Dublin in 1925, is 14-year-old Nan Cantwell, through whom the model of the family cell is reinscribed in part as a result of her father's death, which forces her to leave school and manage the household. What Smith refers to as "the fiction of Irish cultural purity" denies adolescence and the maturing female body, and the classroom becomes a microcosm of the containment culture. Modeled by the habits of the nuns, the fiction of perpetual pre-adolescent androgyny is maintained and rewarded in the classroom, inextricably tied to the girls' social and academic success. Their teacher, Sister Immaculata, tells them, "In regard to those parts of your bodies which are not actively engaged in saying your prayers and learning your lessons, you need remember only three things: cleanliness, concealment, mortification ${ }^{6 "}$. Girls who outgrow their uniforms are made to stand in front of the class while stiff, rustling newsprint is affixed to their skirts, and questions about classroom policies are to be directed to the Virgin Mary, whose likeness is prominently positioned in the classroom. Ultimately, every aspect of the developing self is denied, and the "mortification" practices ritualize the figurative death of sexualized bodies. 
5 The containment culture is similarly modeled in the domestic space. Most of Boylan's narrative is set in the Cantwell home, which is governed strictly by Nan's father, who owns a corset factory. His signature product, the Cantwell, invented "for the inhibition of female obesity", reinforces the school motto of "cleanliness, concealment, mortification". The Cantwell corset becomes a trope for sexual control, the female body an unruly body inferior to its male counterpart. As an agent of female containment and concealment, Mr. Cantwell supports Catholic efforts to suppress physical maturation, and observes Nan's "woman's figure defying the confines of [her] pretty little dress", by which he is "offended". Paradoxically, when he later discovers that she is binding her breasts (unwittingly following the flapper fashion), he sees her self-imposed concealment as equally seditious, accusing her of "flaunting [herself], flat as a washboard" and "tying down her chest like common women in the street... parading herself for men". Both when she conceals her developing chest and when she does not, Nan is betrayed by her body. When the corset begins losing customers who favor modern, less restrictive undergarments, Mr. Cantwell becomes a benefactor for down-on-their-luck women, who are "rehabilitated" by the corset fortune, put to work in the factory and given corsets to wear under their shabby clothing.

Inglis argues that "to understand Irish attitudes to sexuality it is necessary to place them within the wider context of Victorian attitudes to women, marriage, and the family". Within this model, "the woman was seen as the moral savior of her baser mate" and was "held responsible for what took place during encounters with the opposite sex". Though the Cantwell corset is based on the converse premise, it attempts to fashion the Irish woman into a Victorian model of physical and moral restraint, shown most directly in the attempted gentrification of fallen women, contained by the corsets and by the Cantwell home and thereby made respectable. Inglis points out that within the Victorian "double standard men had sexual recourse to servants and prostitutes ${ }^{10}$ ", and this double standard takes on an imperial dimension in Boylan's novel when Mr. Cantwell's colonial wife, heretofore an acquisition left behind with his other colonial duties, arrives from India to take up residence with his Irish family. In addition to working compatibly with Catholic ideals, the Victorian model offered class mobility, and self-restraint was a characteristic of the bourgeoisie ${ }^{11}$. The Cantwell name, in addition to representing women's sexual (self-) restraint, is also the foundation of a capitalist empire, one upon which the Cantwell women are dependent.

The protagonist of Blessed Art Thou A Monk Swimming, set in 1960s Dublin, is 16-year-old Marian O'Dea, who, after being expelled from two schools, in the novel's last scene is sailing to England to follow her actor boyfriend. For Marian, whose life has been shaped by the Constitution and by modern milestones including Vatican II, Ireland's initial efforts to gain admittance to the European Economic Community, and the introduction of Telefís Éireann ${ }^{12}$, access to information and sexually suggestive entertainment, and opportunities for travel outside the country are considerably greater than they were in the 1920s. Still, the girls in Dunne's novel are subjected to rules developed to uphold the containment culture. Marian is discouraged from participating in sports by the threat of physical consequences specific to the female body: "a whack from a ball [to the breasts] meant instant cancer ${ }^{13}$ ". The female body, constructed as a self-sabotaging liability, is disconnected from the female subject through alienation tactics that Conrad argues were later employed by the anti-choice movement to destabilize women's political agency ${ }^{14}$. Girls are also forbidden to use tampons, "as Irish Catholic doctors not only considered 
them undesirable, but discovered that unhealthy discharges occurred in certain cases after using them ${ }^{15}$ ". While the undesirability of tampons is presented as a case supported with medical evidence, this rule seems to be the product of moral objections to the penetrating tampons, rejected in favor of externally affixed pads. Symbolically, the introduction of the tampon offered a method of more directly concealing or "containing" menstruation. However, the invasive nature of the tampon was clearly deemed more objectionable than the release of menstrual blood. Prior to her expulsion for reading a sex pamphlet, Marian is banished to the infants' table in the dining hall and forbidden to communicate with anyone. Her forced regression and "excommunication" suggest to Marian and her parents that she is a failure both socially and intellectually, fit only for a protracted and isolated childhood.

In both novels, the protagonists are surrounded by unhappy women resigned to their unhappy marriages, and within this framework, the role of the mother would seem to be limited. Inglis suggests that Irish mothers "had to enforce the same strategies of sexual control on their daughters as had been enforced on them ${ }^{16 "}$, and indeed both fathers and both mothers actively attempt to manage and exploit their daughters' sexuality. Nan's father encourages one of his friends to grope her, even leaving them alone in the kitchen, and Nan's mother's limited involvement with her daughters consists primarily of her advising Nan to accept her role as a passive agent of her sexuality, telling her after she is groped and called a "bitch" by a boy at a party, "You will do a lot of things you don't like when you are a grown-up ${ }^{17 "}$. Following her husband's death, in a scene reminiscent of Joyce's "The Boarding House", Mrs. Cantwell chastises Nan for being "hopeless" when she resists the family's wealthy middle-aged boarder after he assaults her in his car. In Dunne's novel, Marian's father tries to seduce her when he is drunk and sobs when she resists his clumsy attempts. She is later groped by the parish priest, who attempts to take her on a beach holiday and suggests nude swimming, which her mother encourages, insisting that "it's good to have a priest in the house" and telling Marian, "I hope you'll find some way to repay him for all his kindness ${ }^{18}$ ". Both protagonists are subjected to inappropriate sexual partners chosen for them for their ability to offer stable marriages, proper homes, and normative standards of sexuality. In Marian's case, her options are to sleep with her father or the priest, both arrangements having taken shape within the walls of the family home.

Irish culture and society are often analyzed within the easy binary of tradition and modernity, with the simplistic and problematic suggestion that tradition is the source of oppression and that modernity, often defined by external forces, offers liberation from tradition, bringing with it a superior set of cultural values. Luke Gibbons, paraphrasing Sean O'Faolain, suggests that "modernization is not solely an external force, but [one that] requires the active transformation of a culture from within, a capacity to engage critically with its own past ${ }^{19}$ ". In both novels, the protagonists are confronted not only with defining movements in cultural modernity but also with the dilemma of resisting or embracing modern influences, especially as they are applied to women. The term "New Woman", first used in 1894, "rapidly acquired popular currency as a label for the energetic and independent woman struggling against the constraints of Victorian norms of femininity ${ }^{20 "}$. As the modern woman developed alongside new technologies and forms of entertainment of the early twentieth century, she became associated not only with the external markings of modernity - new fashions and styles designed to accentuate female sex appeal - but with purchasing power, financial independence, and, consequently, a 
lessened dependence on marriage. In her analysis of images of women in issues of Modern Girl and Ladies Irish Home Journal from 1935, Louise Ryan notes that the modern girl was "constantly active and busy", was usually employed in an urban setting, often lived alone, and had enough disposable income to pursue leisure activities, often in a rural setting ${ }^{21}$. With their narrative set in 1925, the characters in Holy Pictures exist in a period of newfound independence and on the cusp of the golden age of cinema, with access to American film and an international marketplace. The introduction of modern entertainment and consumerism presented a clear threat to the Catholic purity narrative, the result of which was "almost hysterical Puritanism ${ }^{22}$." Inglis posits that Irish culture effectively censored sexually informative, suggestive, and explicit materials during the nineteenth century; however, the introduction of the cinema - mass-produced narratives often including romantic and sexual storylines - made sexuality virtually uncontrollable, and

over the last fifty years we have moved in Ireland from a Catholic culture of selfabnegation in which sexual pleasure and desire were repressed, to a culture of consumption and self-indulgence in which the fulfillment of pleasures and desires is emphasized. While this shift reflects not so much sexual liberation as a transition from one sexual regime to another, the clash of cultures can produce insecurity and instability at the heart of ordinary everyday life, which can in turn have repercussions for the general way that people deal with desire and pleasure ${ }^{23}$.

11 In addition to the Hollywood films, American jazz, and European fashions that threaten sexual containment and offer access to information typically suppressed within the family cell, one of the greatest perceived threats in both novels is the retail chain Woolworth's, where girls and young women have easy access to products such as earrings, powdered bath salts, and Bourjois perfume. A threat to Catholic constructions of female identity, the ability to re-create oneself in the image of the "modern woman" prompts the sign posted by the nuns in Marian's dormitory: “CHILDREN OF QUALITY DO NOT LINGER LONG IN WOOLWORTHS." More significant than the sum of its parts, however, is Woolworth's acting as a site of consumer culture wherein female subjects otherwise contained within the cells of the church and the home become active shapers of the economy and of the image of the female Irish citizen. Rita Felski argues that the "belief that Western history has repressed erotic drives through a prevalent ethos of discipline and self-restraint is called into question by the central role of hedonistic desire and sexualized representations in the rise of modern consumerism ${ }^{24 "}$. Focusing on the late nineteenth century and the turn of the century, she identifies the dedication of urban space to women's needs and desires, and the breakdown of the public-private dichotomy as effects of women's becoming more active consumers. The tension between repression and desire is clear in an examination of the threat posed by Woolworth's, which does not merely cater to the pre-existing needs of girls and women but which creates new desires and introduces products designed to adorn and exaggerate the female body, goals certainly at odds with the cultural impulse to conceal and contain it.

In Boylan's novel, Woolworth's also represents an alternative to the influence of the church, the family, and marriage. When she leaves school, Nan's friend Dandy takes a job at Woolworth's and is physically transformed, made nearly unrecognizable by lipstick and green eyeshadow. Her ability to support herself allows her to leave her abusive father and makes her less reliant on marriage than she otherwise would be. Furthermore, as passive agents of their sexuality offered by their parents as commodities to would-be husbands, the girls have access to commodities that allow them to redefine their 
sexuality and market it on its own terms. This sexualization of the adolescent body moves it from the contained realm of the private to the public realm where the female body is displayed for public consumption, used to sell itself and modern female sexuality. Girls and women become more active agents in the commodification of their own bodies and images, and, while shaped by the marketing strategies used to commodify both the desire for the product and the desire for the enhanced female body, are granted certain freedoms by buying into the image of the "modern woman". Felski's study links fin-desiecle consumerism to anxiety created by the seductive powers of consumerism. If women were to be seduced by advertising, by commodities, and by their own purchasing power, they would no longer control their desires, the effect of which, she argues, is that the "subject is decentered", becoming "prey to the beguiling forces of publicity and the image industry ${ }^{25}$." For the protagonists of Boylan's and Dunne's novels, both are aware of the allure offered by the commodification of femininity and its potential use as sexual power, and for both, such commodification makes the female body an "appropriate" object of male consumption. As already decentered subjects trained to conceal, deny, and figuratively kill the body, both gain some control of their desires and of their agency in constructing a sexually developing body, one that is consciously presented to partners of their choosing.

In addition to the roles played by the church and the normative family model, the tendency to suppress awareness of class status and money is clearly tied to sexual containment, and Boylan critiques this connection fairly overtly through the Jewish family in Holy Pictures. The scene in which Nan gets her first period in the Schweitzers' home crystallizes the relationships among modernity, consumerism, and sexual selfawareness. Boylan traces her depiction of the Schweitzer family to her own experiences as a youngster in Dublin:

When I was a kid I remember being very attracted to Jews simply because of this reason: they were the only people I knew who talked about money. Money could never be talked about under any circumstances among Catholic and Protestant families and we grew quietly poorer and poorer. ... Among the Jews it was an honourable thing, business is an honourable thing and poverty was not a shame. Nor indeed was sex, as in Holy Pictures, when the little girl first menstruates and she goes to the Jewish family and they celebrate this and then she goes home and tells her mother and her mother sort of furtively says, "there are some rags in the box on the shelf." She knows then it's something to be ashamed of. I do remember that when I was a kid, hanging around the Jewish families because they seemed to me the only people who really knew how to live; they didn't seem to be absolutely doomed ${ }^{26}$.

14 For nearly all the characters in the novel, the Schweitzers are associated with business transactions and cultural otherness. Before going to their home to buy a hen, Nan imagines it to be exotic and is disappointed by its ordinariness. However, she discovers there a foreign sensibility in which the women celebrate menstruation and Hollywood glamour. Nan begins to replace the traditional "holy pictures" with glamorous images of film stars, part of the zeitgeist in which her peers gradually direct their worship "to Lillian Gish and women in the real world ${ }^{27 "}$. Through this reinscribed iconography of femininity and womanhood, Nan's passivity in her own image construction (the newsprint being pinned to her skirt) is replaced with a more active role. The catalyst for this change is a conflation of entering a "foreign" household, conducting business with a family that is regarded with suspicion, and experiencing her physical maturation in a woman-centric household marked by cultural modernity. 
15 Another byproduct of the modernizing forces at work in both 1920s and 1960s Ireland is unprecedented access to information. While some of this information is manipulated to foster consumer desire, some allows women to counter the deliberate obfuscation of information that, for example, leaves girls unprepared for menstruation, sexual activity, and childbirth. Both protagonists are the products of households in which sex is discussed only in veiled references, and her mother's attempts at propriety result in Marian's solitary imaginings: “Men, [Marian's mother] claimed, were only after the one thing. She'd said it so many times I didn't listen any more. I wasn't even sure what she meant. The only thing I could think of was something awful like the man wanting to pee into the woman's tummy button ${ }^{28}$." Given that sources of information are limited and inaccurate, both Nan and Marian look elsewhere, Nan primarily to Nellie, the Cantwells' maid, who, though prone to inaccuracy and exaggeration, is frank with the children both the excitement and disappointment of sexual experiences. Among Marian's peers, England serves a similar purpose: it is the source of the illustrated sex pamphlet that leads to Marian's expulsion and where she writes to order the necessary supplies for a "guaranteed" 40-inch bust. In both novels, access to information to some extent offsets the likelihood that the physical body will be an "informer" - a catalyst for punishment, alienation, and mistrust.

As a citizen of 1960s Dublin, Marian is afforded a level of transnational mobility that is unlikely to ever be an option for Nan, and Dunne identifies Marian as a postcolonial subject of sorts: "England's colonization ended two or three generations ago. Since then we've been trying to shake off another form of colonization, the Catholic Church, which has had a far more damaging effect on Irish society and culture". Marian, she says, "has the insouciance of youth and the cheerful optimism that something better will turn up ${ }^{29 "}$. With more resources and options than Nan has, Marian, like her predecessor, will gradually begin to imagine a life beyond the boundaries that would seem to dictate her future. In the novel's final scene, when approached by a representative of the Catholic Youth Society, Marian assures her that she has a Catholic home in which to stay and later flushes the address of the parish priest in London down the toilet. As the boat sets out, Marian decides, "This time I'll live. Even if it kills me $e^{30 "}$. Her determination to "live" at all costs requires her leaving Ireland and rejecting the influence of the church and family cells.

17 Boylan suggests that modernization was a catalyzing force in making possible the ability for women to "hold out" for something better, having stated in a 1999 interview, "I think that Ireland was quite a primitive society and I think it's evolved. Due to travel, maybe. Up to the sixties, the travel all went one way. People emigrated and they stayed away. Now you've got simple traveling and coming back, and I think that's the hugely positive influence on everything in the country ${ }^{31}$ ". At the end of Blessed Art Thou A Monk Swimming, Marian's future, including whether she will return to Ireland, is unclear. However, Dunne's asserting that Marian "is holding out for something better than the life around her ${ }^{32 "}$ suggests that she is likely to be able to live only outside Irish borders. Just as Boylan's characters are limited in their options, Marian's mobility is limited, as she has little to return to. From her perspective, at least, she must choose stasis or emigration.

Boylan's characters, on the other hand, while seemingly trapped in Dublin with limited options, suggest that the culture of containment might be resisted in ways that neither passively accept nor actively reject Irish history and tradition. Boylan suggests that the characters' grim outlook is an artifact of the cultural ethos of protracted penance: "The 
old thing, which was so prominent in Ireland, is going - you've made your bed, you must lie in it... It heightened the pleasure of your own acceptable existence to see somebody else within the same framework who was miserable ${ }^{33}$." The character of the young priest significantly challenges this ethos, representing modernity by challenging the mortification rituals embraced by the nuns. As Father Percy, described as an "impudent looking... boy", quizzes the students, Nan "kept her head down, hoping he would choose someone less amply built. It was as if he had deliberately picked on all the most immodestly contoured girls in the class". He insists, "Let's have no more of this nonsense. Take out those pins at once. All of you girls seem ashamed of your bodies. Your bodies are God's work. Are you ashamed of God's work?" as "Our Lady looked on mournfully"34". Father Percy's championing a less restrictive attitude toward women's bodies suggests the possible arrival of a generation less inclined to demand concealment as well as a male perspective on women's modesty that is decidedly less shamebased than the position enforced by the nuns. Although his presence is limited and his influence insignificant as compared to that of the nuns, Father Percy attempts to reverse the pattern of self-denial so central to the fictive narrative of cultural purity.

The adolescent female characters themselves also actively resist the culture of containment, including normative models of marriage. Doll Cotter, who "would not go away" while pregnant, eventually marries a Jewish man, suggesting not only an exogamous attempt to resist a prescribed life but also an attempt to align herself with the group that, to a young Boylan, seemed the only group that was not "absolutely doomed". Nan, who is curious about boys and Doll's pregnancy, experiences her most powerful and intimate feelings through her friendship with Dandy: "They had loved the scent of each other, the grains of dirt in one another's hands. She could not envisage this layering with a man. Romance was all right but she could not endure a pooling of utilities... The men's beds were primitive territory. Sometimes they carried a jungle smell as if to warn off other animals ${ }^{35}$ ". Felski posits that the bildungsroman's female protagonist, identified with "acquiescence, dependency, and powerlessness", often gravitates toward homosocial or homosexual relationships, a "transference of allegiance" that attempts to counter "the negative value which women have been conditioned to place upon their own sex ${ }^{36 "}$. Although Nan's conscious rejection of a patrilineal pooling of resources may not evolve into actions that threaten the stability of the family cell, at the end of the novel, while standing in for both Nellie and her mother, she resists the advances of the boarder, who theoretically offers financial security and a socially acceptable marriage, and looks forward to her younger sister's becoming self-sufficient and offering her release from the maternal (and possibly heteronormative) role.

The Boylan character who most directly suggests the ability of girls and women to challenge containment culture is Dandy. Rejecting only the aspects of her life that directly cause her pain, unlike many of the characters in both Boylan's and Dunne's novels she does not aspire to emigration. In her study of Modern Girl and Ladies Irish Home Journal, Ryan notes that

editorials, features and advertisements attempt to blend fashionable, foreign influences with Irish culture, heritage, landscape and lifestyles. The "modern girl" neither rejects nor denies her Irishness. She is not overtly constructed as the antithesis of all things traditional and Irish. There is no obvious dichotomy between modernity and tradition. Instead, a particular view of Ireland and Irishness is offered. Far from being backward and insular, Ireland is presented as an outward looking country which can embrace modernising influences while retaining its own 
unique identity; rather like the modern girl herself. She is represented as confidently cosmopolitan while firmly located within metropolitan Dublin ${ }^{37}$.

21 Although she dreamed of attending university and traveling the world, without a formal education Dandy more realistically begins a professional life in Dublin, saving her wages to help her sister accrue a dowry for the convent. Her income affords her some degree of independence at age fourteen and is returned to Ireland, even supporting the religious order and educational system she was forced to leave. While it is not clear if she will attain the level of modernity depicted in such periodicals - the financial means to afford domestic help and exotic foods, for example - she supports Irish culture financially and symbolically while integrating modern influences that challenge stasis and insularity.

Though the girls in both novels are urged to manage the "unruly" aspects of their bodies and to train their minds in ways that mimic the habits worn and rote prayers recited by the nuns, little suggests that the nuns attempt to recruit the girls. The influence of Mariolatry offers girls an impossible model, and they are simultaneously trained for virginity and marriage. In the context of DeValera's Ireland, the girls would seem to serve the national interests more effectively as mothers than as nuns, and the girls are routinely rejected from school-sanctioned activities (often for reasons beyond their control) and, in Marian's case, expelled from school entirely, suggesting that membership in the school and church are both exclusive and elusive. Marian notes that some nuns "did all the hard work and could never become Mothers because they were too poor to bring a dowry when they entered the convent". ${ }^{38}$ Less an alternative to marriage than a variation on it, convent life was an option only for those whose families could afford it, and girls' futures in any of the roles for which they were trained were dictated by their fathers' incomes. Dandy's saving her wages to help her sister enter the convent, then, not only permeates the economic equation otherwise dictated by the financial standing of men but also uses the money of the modern nemesis, Woolworth's, to do so.

Dandy's sister, too, seems to make a choice that allows her to escape the prescribed options of marrying and repopulating the nation. While the nuns are complicit in enforcing the rituals of concealment and mortification, as agents of the church they do arguably attain a level of freedom not offered to women who marry. Elizabeth Butler Cullingford points out that while "many feminists who oppose patriarchal Catholicism see nuns as complicit with a traditional system that both dominated and devalued them", research has recognized the convent as "a privileged space where women could reject marriage and childbirth, choosing to live, work, and love within a traditional community that offered them more cultural power and self-determination, and possibly more sensual satisfaction, than was to be found within the home ${ }^{39 "}$. After collecting interviews with women who served in Irish religious orders between 1910 and 1940, Yvonne McKenna posited that nuns offset the binary of female private space and public male space, "valued precisely for their celibacy and the work they did". The women she interviewed said that as "girls and young women, they associated nuns with work, travel, and a life of spirituality whose very clothes, in stark contrast to their mothers', represented professionalism, responsibility, power, and purity". Furthermore, their identity was shaped not by the walls of the home, as was the case for most mothers, but by the experiences they had "out questing, walking, or praying with the other nuns; helping the poor or engaging in other forms of social work; working in schools and hospitals; and flying home from the missions for promotional visits ${ }^{40}$. Dandy and her sister, once 
confined to a family cell characterized by abuse, resist this model without renouncing their Irishness or emigrating.

This reading is not intended to suggest a correlation between the modern periods depicted and the degree of freedom that women in general experienced during those years. Moreover, a significant difference between the novels' constructions of agency is that whereas Marian narrates her own story, Nan's narrative is relayed by a third-person narrator who offers the context and insight of a reflective adult rather than an adolescent girl. Through the novel's narrativity, Boylan offers a layer of objective critique that is clearly not intended by Dunne and that may imagine the characters' futures within the framework of contemporary hindsight. Marian's "insouciance of youth" and "cheerful optimism" make hers a bildungsroman that is protagonist-centric, giving the novel a voice that is both humorous and heartbreaking but that does not offer the mature view or context that a third-person narrator might. Both protagonists, however, as self-aware young women critically engaged with the choices they are forced to make, offer the Irish canon a new image of femininity and female sexuality, one built around the modern Irish girl.

\section{NOTES}

1. Kathryn A. Conrad, Locked in the Family Cell: Gender, Sexuality, and Political Agency in Irish National Discourse. University of Wisconsin Press, 2004.

2. James M. Smith, Ireland's Magdalen Laundries and the Nation's Architecture of Containment. University of Notre Dame Press, 2007, p. 4.

3. Sally Barr Ebest, "These Traits Also Endure: Contemporary Irish and Irish-American Women Writers", New Hibernia Review, 7/2, 2003, p. 58.

4. Ibid., p.60-61.

5. Tom Inglis, "Origins and Legacies of Irish Prudery: Sexuality and Social Control in Modern Ireland", Éire-Ireland, 40/3-4, 2005, p. 13.

6. Clare Boylan, Holy Pictures, London, Abacus, 1983, p. 28.

7. Ibid., p. 64-65.

8. Ibid., p. 130-131.

9. Tom Inglis, op. cit., p.13-14.

10. Ibid., p. 13.

11. Ibid., p. 15.

12. Luke Gibbons, Transformations in Irish Culture. University of Notre Dame Press, 1996, p. 82-83.

13. Miriam Dunne, Blessed Art Thou A Monk Swimming. London, Headline, 1997, p. 7.

14. Conrad, op. cit., p. 70-79.

15. Dunne, op. cit., p. 61. 
16. Tom Inglis, op. cit., p. 18.

17. Clare Boylan, op. cit., p. 88.

18. Miriam Dunne, op. cit., p. 163 and p. 191.

19. Luke Gibbons, op. cit., p. 3.

20. Rita Felski, The Gender of Modernity. Cambridge, Harvard University Press, 1995, p. 146.

21. Louise Ryan, “Constructing 'Irishwoman': Modern Girls and Comely Maidens”, Irish Studies Review, 6/3, 1998, p. 267-269.

22. Yvonne McKenna, "Embodied Ideals and Realities: Irish Nuns and Irish Womanhood, 1930s-1960s", Éire-Ireland, 41/1-2, 2006, p. 42-43.

23. Tom Inglis, op. cit., p. 11.

24. Rita Felski, op. cit., GM 61.

25. Ibid., p. 62.

26. Nainsí J. Houston, How Irish Women Writers Portray Masculinity. Lewiston, Edwin Mellen Press, 2005, p. 155-156.

27. Clare Boylan, op. cit., p. 29.

28. Ibid.

29. Moloney Caitriona and Helen Thompson, Irish Women Writers Speak Out. Syracuse University Press, 2003, p. 44 and p. 47.

30. Miriam Dunne, op. cit., p. 218.

31. Nainsí J. Houston, op. cit., p. 154.

32. Moloney and Thompson, op. cit., p. 48.

33. Nainsí J. Houston, op. cit., p. 153-154.

34. Clare Boylan, op. cit., p. 29-32.

35. Ibid., p. 232.

36. Rita Felski, Beyond Feminist Aesthetics: Feminist Literature and Social Change, Cambridge, Harvard University Press, 1989, p. 83.

37. Louise Ryan, op. cit., p. 271.

38. Miriam Dunne, op. cit., p. 40.

39. Elizabeth Butler Cullingford, “'Our Nuns Are Not a Nation': Politicizing the Convent in Irish Literature and Film”, Éire-Ireland, 41/1-2, 2006, p. 10-11.

40. Yvonne McKenna, p. 40 and p. 49.

\section{ABSTRACTS}

This article examines the novels Holy Pictures by Clare Boylan and Blessed Art Thou A Monk Swimming by Miriam Dunne within the framework of the notions of Ireland's culture of sexual containment and the family cell. While Dunne's novel, set in Dublin in the 1960s, reflects a level of transnational mobility not afforded to the characters in Boylan's novel, set forty years earlier, 
Boylan suggests modes of resistance that allow her female characters to challenge the containment culture, influenced by the modern images of femininity and female sexuality constructed by advertising and Hollywood films. Furthermore, Boylan suggests the possibility of challenging constructions of female identity without emigrating or compromising national identity.

Cette analyse aborde les questions de la répression sexuelle et de la cellule familiale dans la culture irlandaise à travers les romans Holy Pictures de Clare Boylan et Blessed Art Thou A Monk Swimming de Miriam Dunne. Le roman de Dunne, qui se déroule à Dublin pendant les années soixante, met en scène une certaine mobilité géographique interdite aux personnages du roman de Boylan, qui se passe 40 ans plus tôt. Boylan suggère des modes de résistance qui permettent aux personnages féminins de surmonter la culture de la répression, culture définie par les images modernes de fémininité et de sexualité féminine cultivées par les médias et les films de Hollywood. En fait, Booylan explore la possibilité de mettre en question les constructions de l'identité féminine sans passer ni par l'emigration ni par la mise en péril de l'identité nationale.

\section{INDEX}

Keywords: Boylan Clare, Dunne Miriam, women - literary representations, sexuality

Mots-clés: femmes - représentations littéraires, sexualité

\section{AUTHOR}

\section{KELLI MALOY}

University of Pittsburgh at Greensburg 